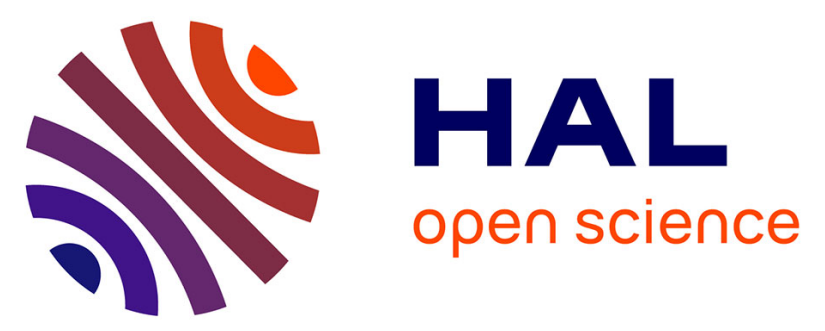

\title{
Ecological adaptation in Lolium: morphological and physiological parameters at early stages of growth in two varieties with different degree of persistence
}

Sergio Arcioni, Francesco Damiani, Domenico Mariotti

\section{- To cite this version:}

Sergio Arcioni, Francesco Damiani, Domenico Mariotti. Ecological adaptation in Lolium: morphological and physiological parameters at early stages of growth in two varieties with different degree of persistence. Agronomie, 1985, 5 (2), pp.181-186. hal-00884748

\author{
HAL Id: hal-00884748 \\ https://hal.science/hal-00884748
}

Submitted on 1 Jan 1985

HAL is a multi-disciplinary open access archive for the deposit and dissemination of scientific research documents, whether they are published or not. The documents may come from teaching and research institutions in France or abroad, or from public or private research centers.
L'archive ouverte pluridisciplinaire HAL, est destinée au dépôt et à la diffusion de documents scientifiques de niveau recherche, publiés ou non, émanant des établissements d'enseignement et de recherche français ou étrangers, des laboratoires publics ou privés. 


\section{Ecological adaptation in Lolium : morphologi- cal and physiological parameters at early stages of growth in two varieties with different degree of persistence}

Sergio ARCIONI, Francesco DAMIANI \& Domenico MARIOTTI

Centro di Studio per il Miglioramento Genetico delle Piante Foraggere del C.N.R., Facoltà di Agraria, Borgo $X X$ Giugno, 06100 Perugia (Italy)

Two differently adapted varieties of Lolium perenne L., characterized by contrasting level of persistence in the Mediterranean environment, were evaluated during the initial period of plant growth for some physiological and morphological traits. No differences were observed when plants were grown at $20^{\circ} \mathrm{C}$. At $10{ }^{\circ} \mathrm{C}$, the temperature of spring growth, the two cultivars differed in root and shoot development and water soluble carbohydrate content, while at $30^{\circ} \mathrm{C}$, the temperature characterizing the summer stress period, they differed in $\mathrm{CO}_{2}$ uptake and specific leaf weight. The results are discussed in relation to the role of the differences in the early stage of plant growth on persistence of the two varieties.

Additional key words : Lolium perenne, Mediterranean climate, physiological parameters.

Adaptation écologique chez Lolium : paramètres morphologiques et physiologiques aux premiers stades de croissance chez deux variétés de persistance différente.

Quelques caractères morphologiques et physiologiques de deux variétés de Lolium perenne $\mathrm{L}$., de niveau différent de persistance en milieu méditerranéen, sont étudiés pendant la période initiale de croissance. Aucune différence n'est observée à $20^{\circ} \mathrm{C}$. A $10^{\circ} \mathrm{C}$, température de croissance printanière, les deux cultivars se distinguent par le développement des racines et des pousses anns que par leur teneur en carbohydrates hydrosolubles et à $30^{\circ} \mathrm{C}$, température de stress estival, par leur consommation en $\mathrm{CO}_{2}$ et leur poids foliaire spécifique. Les résultats sont discutés dans la perspective du rôle des différences observées aux stades jeunes de croissance sur la persistance des deux variétés.

Mots clés additionnels : Lolium perenne, climat méditerranéen, paramètres physiologiques.

\section{INTRODUCTION}

Varieties of Lolium perenne L. often show lack of adaptability when moved out of their areas of adaptation and breeding (KNIGHT, 1966). For example North European varieties when cultivated in the Mediterranean environment, despite a valuable dry matter yield during the first year, show, as compared with adapted varieties, a strongly reduced persistence in the following years (FAlCINELli \& CECCARELli, 1977). A possible explanation of this behaviour could be the absence in the North European varieties of the specific summer-dormancy mechanism (SILSBURY, 1961) which, in adapted cultivars prevents stresses due to Mediterranean climate. Closely related to the lack of summer dormancy is the large consumption of carbohydrate reserves, not restored by the reduced photosynthesis, in stubble and roots during the summer period characterized by reduced growth activity (WARD \& BLASER, 1961 ; DAVIDSON \& MILTHORPE, 1965 ; DAVIES, 1965 ; MILTHORPE \& DAVIDSON, 1966 ; SHEARD, 1968 ; ALBERDA, 1970 ; BOOYSEN \& NELSON, 1975). The resulting low level of reserves can lead to reduced regrowth in autumn, culminating in gradual disappearance of unadapted varieties (ARCIONI et al., 1980; MARIOTTI et al., 1981). The relationships between the physiological aspects of forage production and adaptation must be studied to understand the lack of persistence in non-adapted varieties. Since the first phases of plant 
growth are involved in the establishment of the pasture and offer the possibility to select plants at an early stage, with remarkable practical advantages, they represent a suitable phase for investigating the phenomenon of adaptation. This paper evaluates some physiological parameters related to dry matter yield in two differently adapted varieties of $L$. perenne, during the first 8 weeks from seedling emergence.

\section{MATERIALS AND METHODS}

Two varieties of $L$. perenne L. 'Vejo' (cultivar adapted to Central Italy) and 'Lenta' (Danish variety adapted to Northern European environment) were used.

\section{A. Plant growth and leaf morphology}

Seeds of each variety were sown in pots (one seed per pot) and the plantlets grown in two different growth-cabinets (40 plants per cabinet arranged in eight rows of five pots each, surrounded by guard plants) under the following conditions: $14 \mathrm{~h}$ of photoperiod characterized by different light intensities and temperatures (1st hour $135 \mu \mathrm{E}$ and $17{ }^{\circ} \mathrm{C}$, 2nd hour $250 \mu \mathrm{E}$ and $19^{\circ} \mathrm{C}$, from the 3 rd to 12 th hour $450 \mu \mathrm{E}$ and $20^{\circ} \mathrm{C}$, 13th hour $250 \mu \mathrm{E}$ and $19^{\circ} \mathrm{C}$, 14th hour $135 \mu \mathrm{E}$ and $17{ }^{\circ} \mathrm{C}$ ) ; during the dark period temperature was maintained at $15^{\circ} \mathrm{C}$; the relative humidity was around $65 \%$. To make lighting uniform, the growth cabinets were equipped with aluminized reflective walls and pots were daily moved by one position in two fixed orthogonal directions.

The following traits were examined: daily elongation of the 2 nd leaf ( $\mathrm{mm} /$ day), rate of leaf appearance of the first 6 leaves on the main tiller (days from seedling emergence), lerigth of the first 6 leaves $(\mathrm{mm})$, width of the 6 th leaf measured at $1 \mathrm{~cm}$ from the ligule $(\mathrm{mm})$, date of $1 \mathrm{st}$ tiller appearance (days from seedling emergence), number of tillers per plant evaluated at the emergence of the 6th leaf, frequency $\left(\mathrm{n} / \mathrm{mm}^{2}\right)$ and size $(\mathrm{mm})$ of stomata.

Leaf impressions of the fully expanded 6th leaf were made according to SCHOCH \& SILVY (1978); the impressions of the adaxial, center leaf-blade were mounted on microscope slides. Stomata were counted in 40-50 microscopic fields (100 $\times$ magnification). Stomatal size was estimated by measuring exterior guard cell lengths of 5 stomata per leaf per plant using $400 \times$ magnification. A micrometer scale was used to calibrate measurement.

\section{B. $\mathrm{CO}_{2}$ uptake at various photosynthetic photon flux densities}

As in the previous experiment, eighty plants (40 per variety) were sown in stages sown (15 seeds per week) and grown in cabinets under the conditions described above. When the plants showed the 5 th or 6 th tiller (around the 40th day) net photosynthesis rate (NPR) was evaluated at $20^{\circ} \mathrm{C}$ at various photon flux densities at leaf surface $(49,100,200,290,575,800$ and $\left.1000 \mu \mathrm{E} \mathrm{m} \mathrm{m}^{-2} \mathrm{~s}^{-1} \mathrm{PAR}\right)$. Net photosynthesis was measured in a $\mathrm{CO}_{2}$ assimilation chamber in an open system connected with an infrared gas analyzer (GRUBB \& PARSON mod. 120). Five or six detached leaves were enclosed in a ventilated chamber. Leaf temperature, maintained constant by a refrigeration system, was controlled by using a copper-constantan thermocouple in contact with the lower surface of one of the leaves. Gas entering the chamber was saturated with water. After photosynthesis measurement the photosynthetic leaf area and leaf weight were determined.

\section{Evaluation of physiological parameters}

Ninety seeds of each variety, previously weighed, were sown in two subsequent weeks (45 plants $x$ variety $\times$ week) in pots. The plants were arranged in a cabinet as previously described and grown under the same conditions as in the above-reported experiment except for temperature which was constantly maintained at $10^{\circ} \mathrm{C}$. Net photosynthesis was evaluated, as previously described, on 15 plants $\times$ variety $\times$ replicate (4 replicates) under a photon flux density of $575 \mu \mathrm{E} \mathrm{m} \mathrm{m}^{-2} \mathrm{~s}^{-1}$ of PAR (corresponding to light saturation of $\mathrm{CO}_{2}$ uptake) and at the same temperature of plant growth. After 45 days from sowing, the 30 remaining plants were uprooted, carefully washed, and shoots were cut at $2 \mathrm{~cm}$ from the crown. For each plant the number of tillers, the root and shoot dry weight and the water-soluble carbohydrate (WSC) content in roots and basal stems were determined according to SMITH \& GROTELUESCHEN (1966). The same procedure was followed to evaluate the above described traits on plants grown at $20^{\circ} \mathrm{C}$ and $30^{\circ} \mathrm{C}$.

\section{RESULTS AND DISCUSSION}

COOPER \& EDWARDS (1961) reported that total leaf area per plant is determined by number of tillers per plant, rate of leaf appearance and leaf size ; marked differences in growth responses often occur between populations of the same species from different climatic origin (EvANS et al., 1964).

Table 1 reports different traits examined during the early phases of plant growth. The environmental conditions used resembled those of the spring and hence were optimal for plant growth. In these conditions 'Lenta' showed leaf elongation rate and length of $1 \mathrm{st}$, 2nd and 3rd leat significantly higher than 'Vejo'. Starting from the 4th leaf the two varieties did not reveal any further significant differences. On the contrary 'Vejo' had a leaf emission rate faster than 'Lenta' : in fact the 6th leaf appeared in 'Vejo' one day and a half earlier. Difterences were observed neither in the date of appearance of 1st tiller nor in the number of tillers per plant counted at the appearance of the 6 th leaf. The data did not reveal large differences between the two varieties for total leaf area because the greater leaf size of 'Lenta' was counter-balanced by its slower rate of leaf appearance. Similar results have been reported by COOPER \& EDWARDS (1961). The significant differences observed for the length of first leaves could be related to 
TABLE 1

Morphological traits during the first phases of plant development in two varieties of $\mathrm{L}$. perenne grown under controlled conditions. Caractères morphologiques pendant les premières phases de développement de deux variétés de $\mathrm{L}$. perenne cultivées en conditions contrôlées.

\begin{tabular}{lcccc}
\hline \multicolumn{1}{c}{ Traits } & Lenta & Vejo & L.S.D. \\
\hline & & & & \\
Elongation of 2nd leaf & & & \\
(mm/day) & & 10.62 & 9.24 & $*$ \\
Rate of leaf appearance (days) & 9.2 & 8.9 & $*$ \\
6th leaf appearance (days) & 57.5 & 56.0 & $*$ \\
& 1st & 61 & 45 & $* *$ \\
Length of the first 6 leaves & 2nd & 97 & 85 & $*$ \\
(mm) & 3rd & 139 & 124 & $*$ \\
& 4 th & 181 & 170 & n.s. \\
& 5 th & 214 & 206 & n.s. \\
Width of the 6th leaf (mm) & 6 th & 218 & 214 & n.s. \\
Date of 1st tiller appearance & & 4.9 & 4.6 & n.s. \\
(days) & & 24.5 & 22.9 & n.s. \\
Number of tillers per plant & & 15.9 & 15.3 & n.s. \\
Stomatal frequency (n/mm ${ }^{2}$ ) & & 53.1 & 49.3 & n.s. \\
Stomatal size (mm) & & 0.039 & 0.037 & n.s. \\
& & & & \\
\hline \hline
\end{tabular}

* Significant $\mathbf{P} \leq 0.05$.

** Significant $\mathrm{P} \leq 0.01$

n.s. Not significant.

the higher seed weight (reported as a genetic feature) characterizing the $\mathrm{cv}$. 'Lenta' respect to 'Vejo' (2.46 mg vs. $1.46 \mathrm{mg}$ single seed weight) (VERONESI $e t$ al., 1983).

Stomata provide the major pathway for both photosynthetic $\mathrm{CO}_{2}$ uptake and transpirational water loss. Genetic variation in stomatal frequency and size has been reported for many forage species (WILSON \& COOPER, 1969b; TAN \& DUNN, 1976). Stomatal frequency has been shown to differ on upper and lower leaf surfaces (LIANG et al., 1975). The adaxial surface of $L$. perenne leaf has a much higher number of stomata than the abaxial one (data not shown) and for this reason we considered only the adaxial surface. Both stomatal frequency and size were not found different in the two varieties.
In order to assess physiological differences related to the contrasting breeding environment of the two varieties, net photosynthesis rate (NPR) was measured at $20^{\circ} \mathrm{C}$ under various photon flux densities. As expected the NPR increased when light was raised and saturation point was reached at around $575 \mu \mathrm{E} \mathrm{m^{-2 }} \mathrm{s}^{-1}$ PAR (table 2). No differences were observed between the two cultivars. EAGLES (1967) reported that Danish populations of Lolium perenne reached light saturation at a lower light intensity than Algerian populations. The disagreement with EAGLES' data could be explained by considering that the differences between the environments of Central Italy and Denmark are substantially as large as those between Central Italy and Algeria.

Since no remarkable differences were observed at $20^{\circ} \mathrm{C}$, an experiment at various temperatures $\left(10^{\circ} \mathrm{C}\right.$, $20^{\circ} \mathrm{C}, 30^{\circ} \mathrm{C}$ ) was carried out to evaluate NPR, plant growth parameters and WSC content in roots and basal stems (table 3 ). NPR showed the lowest values at $10{ }^{\circ} \mathrm{C}$, the highest ones at $20^{\circ} \mathrm{C}$ and did not differ

TABLE 2

Net photosynthesis rate (NPR) at different photon flux densities and at $20^{\circ} \mathrm{C}$ in 40-day old plants of two varieties of $\mathrm{L}$. perenne grown under controlled conditions.

Vitesse de photosynthèse (NPR) à différentes densités de flux de photons et à $20^{\circ} \mathrm{C}$ chez des plantes âgées de 40 jours de deux variétés de L. perenne cultivées en conditions contrôlées.

\begin{tabular}{llllllll}
\hline & \multicolumn{6}{c}{ Photon flux density $\left(\mu \mathrm{Em}^{-2} \mathrm{~s}^{-1}\right.$} & PAR) \\
\cline { 2 - 7 } & 49 & 100 & 200 & 290 & 575 & 800 & 1000 \\
\hline $\begin{array}{l}\text { Vejo } \\
\text { NPR } \\
\left(\mathrm{mg} \mathrm{CO} \mathrm{dm}^{-2} \mathrm{~h}^{-1}\right)\end{array}$ & 2.20 & 4.35 & 7.02 & 9.59 & 11.95 & 12.38 & 12.68 \\
$\begin{array}{l}\text { Lenta } \\
\text { NPR } \\
\left(\mathrm{mg} \mathrm{CO} \mathrm{dm}^{-2} \mathrm{~h}^{-1}\right)\end{array}$ & 1.82 & 3.65 & 6.75 & 9.75 & 11.50 & 11.87 & 12.05 \\
L.S.D. & n.s. & n.s. & n.s. & n.s. & n.s. & n.s. & n.s. \\
\hline
\end{tabular}

n.s. Not significant.

TABLE 3

Morphological and physiological parameters in two varieties of $\mathrm{L}$. perenne grown at three different temperature regimes $\left(10^{\circ} \mathrm{C}, 20^{\circ} \mathrm{C}, 30^{\circ} \mathrm{C}\right.$ ).

Paramètres morphologiques et physiologiques chez deux variétés de L. perenne cultivées sous trois régimes thermiques $\left(10^{\circ} \mathrm{C}, 20^{\circ} \mathrm{C}, 30^{\circ} \mathrm{C}\right)$.

\begin{tabular}{|c|c|c|c|c|c|c|c|c|c|}
\hline & \multicolumn{3}{|c|}{$10^{\circ} \mathrm{C}$} & \multicolumn{3}{|c|}{$20^{\circ} \mathrm{C}$} & \multicolumn{3}{|c|}{$30^{\circ} \mathrm{C}$} \\
\hline & Lenta & Vejo & L.S.D. & Lenta & Vejo & L.S.D. & Lenta & Vejo & L.S.D. \\
\hline Number of tillers ( $\mathrm{n}$ /plant) & 5.43 & 6.87 & $* *$ & 8.15 & 9.17 & n.s. & 6.17 & 6.11 & n.s. \\
\hline Root dry weight (mg/plant) & 150.83 & 209.07 & ** & 314.52 & 305.11 & n.s. & 79.78 & 82.20 & n.s. \\
\hline Shoot dry weight (mg/plant) & 288.30 & 375.91 & $*$ & 774.81 & 856.35 & n.s. & 221.93 & 219.56 & n.s. \\
\hline Root dry weight (mg/plant) & 0.33 & 0.37 & * & 0.27 & 0.26 & n.s. & 0.27 & 0.28 & n.s. \\
\hline \multicolumn{10}{|l|}{$\begin{array}{l}\text { Root plus shoot dry weight } \\
\text { (mg/plant) }\end{array}$} \\
\hline WSC (mg/plant) & 14.52 & 19.48 & $* *$ & 8.14 & 7.21 & n.s. & 3.40 & 3.30 & n.s. \\
\hline $\mathrm{SLW}\left(\mathrm{mg} / \mathrm{cm}^{2}\right)$ & 3.836 & 3.607 & n.s. & 2.325 & 2.519 & n.s. & 2.098 & 2.376 & $*$ \\
\hline $\mathrm{NPR}\left(\mathrm{mg} \mathrm{CO} \mathrm{Cm}^{-2} \mathrm{~h}^{-1}\right)$ & 5.894 & 5.233 & n.s. & 10.207 & 11.233 & n.s. & 6.903 & 8.020 & $*$ \\
\hline
\end{tabular}

* Significant $\mathrm{P} \leq 0.05$;** Significant $\mathrm{P} \leq 0.01$; n.s. Not significant. 
between the two varieties. Of particular interest are the data at $30^{\circ} \mathrm{C}$ when intermediate values of NPR were recorded and 'Vejo' showed significantly higher values than 'Lenta'. The observed differences between the two types at the extreme temperature characteristic of Mediterranean summer accord with EAGLES' data and reflect the different adaptative strategies of the two varieties. The maximum value of shoot and root dry weight at $20{ }^{\circ} \mathrm{C}$ was in relation with the maximum NPR. On the contrary at $30^{\circ} \mathrm{C}$, despite the intermediate values of NPR, the lowest production of shoots and roots was observed. This situation could be explained by the large increase of dark respiration related to the temperature increase (EAGLES, 1967). Significant differences in favour of 'Vejo' between the two varieties were observed only at $10^{\circ} \mathrm{C}$. This finding confirms that plants of Mediterranean origin have more rapid growth at low temperatures than those of North European origin as reported by COOPER (1964). The root dry weight/root plus shoot dry weight ratio was related to temperature. At $10{ }^{\circ} \mathrm{C}$ the value of this ratio was significantly higher in 'Vejo' than in 'Lenta' (0.37 vs. 0.33$)$. At $20^{\circ} \mathrm{C}$ and $30{ }^{\circ} \mathrm{C}$ the values of the ratio were significantly lower and no differences were observed between the two varieties. Root development in the Mediterranean climate takes place substantially during early spring and late autumn, periods characterized by temperatures around $10^{\circ} \mathrm{C}$, and the significantly higher root development observed in 'Vejo' could give an adaptative advantage during drought stress periods. The trend of number of tillers per plant was similar to that of shoot and root production, confirming the close relationship between DMY and number of tillers (SLEPER et al., 1977 ; LHAMBY, 1978 ; CECCARELLI et al., 1980).

WSC (fructosans, sucrose and glucose plus fructose) represent the energy store which grasses need to overcome stress periods and to support regrowth after defoliation (SHEARD, 1968); their metabolism is obviously related to net $\mathrm{CO}_{2}$ uptake and plant growth. The WSC content $(\mathrm{mg} /$ plant) in roots and basal stems showed highest values at $10^{\circ} \mathrm{C}$ and differences were observed in favour of 'Vejo'. At $20^{\circ} \mathrm{C}$ the WSC content was reduced in both varieties by about 50) $\%$, while at $30{ }^{\circ} \mathrm{C}$ there was the lowest WSC content and no differences were observed between the two types. The highest value in WSC content observed at $10{ }^{\circ} \mathrm{C}$ accords with the typical adaptative strategy observed in grasses, consisting in an accumulation of carbohydrate reserves to prevent cold stress (POLLOCK \& BugGles, 1976 ; Pollock, 1981).
Specific leaf weight (SLW, dry weight per leaf area unit) could be associated with yield through a positive relationship with photosynthesis (TOPARK-NGARM el al., 1977). Genotypic differences in SLW have been found in populations of $L$. perenne (WILSON \& COOPER, 1969a). In our experiment SLW decreased 35 p. 100 and 46 p. 100 from $10^{\circ} \mathrm{C}$ to $30^{\circ} \mathrm{C}$ for 'Vejo' and 'Lenta' respectively while the differences between the two populations became significant at $30^{\circ} \mathrm{C}$ when 'Vejo' had higher SLW. These results indicate, according to NELSON et al. (1978) that Mediterranean populations show markedly less temperature responses than North European ones.

\section{CONCLUSIONS}

During the early phase of growth under the experimental conditions used, the two varieties differ substantially for NPR at $30^{\circ} \mathrm{C}$, root and shoot development at $10^{\circ} \mathrm{C}$, the ratio root dry weight/shoot plus root dry weight at $10^{\circ} \mathrm{C}$, WSC content at $10^{\circ} \mathrm{C}$ and $\mathrm{SLW}$ at $30^{\circ} \mathrm{C}$. It is worth noting that these differences occurred only at 10 and $30^{\circ} \mathrm{C}$, temperatures characterizing the spring active growth and the summer stress periods in Mediterranean areas. The larger root dry weight of the adapted variety at $10{ }^{\circ} \mathrm{C}$ could account for its superior capability to escape summer drought stress. Moreover the larger WSC store of 'Vejo' will surely be an advantage for survival over the summer period and for regrowth after autumn rainfall, when energy cannot be supplied by $\mathrm{CO}_{2}$ uptake due to a strongly reduced total leaf area. At $30^{\circ} \mathrm{C}$ leaf dry weight was similar in both types but SLW was higher in 'Vejo', consequently total leaf area was larger in 'Lenta'. The high level of NPR in 'Vejo' at $30^{\circ} \mathrm{C}$ compensates for its smaller leaf area which on the other hand should reduce water loss by transpiration (WILSON, 1976). Our data demonstrate that some important differences characterize the two varieties since the initial phases of plant establishment and growth. These differences could reflect the contrasting behaviour of the two varieties with respect to persistence and adaptation in Mediterranean regions.

Recu le 29 mai 1984. Accepté le 11 octobre 1984.

\section{AKNOWLEDGEMENT}

Thanks are due to Mr. I. BernaCCHIA, and Mr. G. Olimpieri for valuable technical assistance.
Alberda Th., 1970. The influence of carbohydrate reserves on respiration, photosynthesis and dry matter production of intact plants. Proc. Ilth Int. Grassl. Congr., 517-522.

Arcioni S., Mariotti D., Falcinelli M., Ceccarelli S., 1980. Relationship between ecological adaptation and carbohydrate reserve evolution for 1 wo differen varietics of Lotium perenne $1 .$. Ann. Amél. Plantes, 30, 309-319.

Booysen P., Dev., Nelson J., 1975. Leaf area and carbohydrate reserves in regrowth of tall fescue. Crop Sci., 15, 262-266.
Ceccarelli S., Falcinelli M., Damiani F., 1980. Selection for dry matter yield in Lolium perenne L. II. Correlated responses under two cutting regimes. Can. J. Plant Sci., 60, 501-508.

Cooper J. P., 1964. Climatic variation in forage grasses. I. Leal development in climatic races of Lolium and Dactylis. J. Appl. Ecol., 1, 45-61.

Cooper J. P., Edwards K. J., 1961. The genetic control of leaf development in Lolium. I. Assessment of genetic variation. Heredity, 16, 63-82. 
Davidson J. L., Milthorpe F. L., 1965. Carbohydrate reserves in the regrowth of cocksfoot (Dactylis glomerata L.). J. Br. Grassl. Soc., 20, 15-18.

Davies A., 1965. Carbohydrate levels and regrowth in perennial ryegrass. J. Agric. Sci., 65, 213-221.

Eagles C. F., 1967. Apparent photosynthesis and respiration in populations of Lolium perenne from contrasting climatic regions. Nature, 21, 100-101.

Evans L. T., Wardlaw I. F., Williams C. N., 1964. Environmental control of growth, 102-125. In C. BARNARD : "Grasses and grassland ». Mc Millian, London.

Falcinelli M., Ceccarelli S., 1977. Seasonal productivity and persistence of grass varieties in Central Italy. Proc. 13th Int. Grass/ Congr., 251-258.

Knight R., 1966. The growth of cocksfoot (Dactylis glomerata L.) in a winter rainfall environment. Proc. 10th Int. Grassl. Congr., 308-311.

Lhamby J. C., 1978. Phvsiological characteristic of different forage yielding tall fescue (Festuca arundinacea Schreb.) selections under field sward conditions. M. S. Thesis, Oregon State University.

Liang G. H., Dayton A. D., Chu C. C., Casady A. J., 1975. Heritability of stomatal density and distribution on leaves of grain sorghum. Crop Sci., 15, 567-570.

Mariotti D., Arcioni S., Ceccarelli S., 1981. Molecular weight distribution of fructosan macromolecules in two differently adapted varieties of Lolium perenne L.. Genet. Agraria, 35, 155-164.

Milthorpe F. L., Davidson J. L., 1966. Physiological aspects of regrowth in grasses, 241-255, in J. D. Mil.THORPE \& J. D. IVINS «The growth of cereals and grasses ». Butterworths, London.

Nelson C. J., Treharne K. J., Cooper J. P., 1978. Influence of temperature on leaf growth of diverse populations of tall fescue. Crop Sci., 18, 217-220.

Pollock J. C., 1981. Environmental effects on reserve carbohydrates in Phleum pratense. Proc. Symp. Br. Grassl. Soc. Nottingham. Plant Physiology and herbage production, 115-118.

Pollock J. C., Buggles P. A., 1976. Cold induced fructosan synthesis in leaves of Dactylis glomerata. Phytochemistry, 15, 16431646 .
Schoch P. G., Silvy A., 1978. Methode simple de numération des stomates et des cellules de l'épiderme des végétaux. Ann. Amél. Plantes, 28, 455-461.

Sheard R. W., 1968. Influence of defoliation and nitrogen on the development and the fructosan composition of the vegetative reproductive system of timothy (Phleum pratense L.) Crop Sci., 8 , 55-60.

Silsbury J. H., 1961. A study of dormancy, survival and other characteristics in Lolium perenne L. at Adelaide, S.A.. Ausir. J. Agric. Res., 12, 1-9.

Sleper D. A., Nelson C. J., Asay K. H., 1977. Diallel and path coefficient analysis of tall fescue (Festuca arundinacea) regrowth under controlled conditions. Can. J. Genet. Cytol., 19, 557-564.

Smith D., Grotelueschen R. D., 1966. Carbohydrates in grasses I. Sugar and fructosan composition of the stem bases of severa northern-adapted grasses at seed maturity. Crop Sci., 6, 263-266.

Tan G. Y., Dunn G. M., 1976. Genetic variation in stomatal length and irequency and characteristics in Bromus inermis Leyss.. Crop Sci., 16, 550-553.

Topark-Ngarm A., Carlson T. T., Pearce R. B., 1977. Direct and correlated responses to seliction for specific leaf weight in reed canarygrass. Crop Sci., 17, 765-769.

Veronesi F., Damiani F., Grando S., Falcinelli M., 1983. The influence of seed weight on establishment and productivity in the tïsl year in Lolium perenne L.. Genet. Agr., 37, 391-402.

Ward C. Y., Blaser R. E., 1961. Carbohydrate food reserves and leaf area in regrowth of orchardgrass. Crop Sci., 1, 366-370.

Wilson D., 1976. Physiological and morphological selection criteria in grasses. Rep. Meet. Fodder Crops Sect., Eucarpia, September 7 9, Roskilde, Denmark, 9-18.

Wilson D., Cooper J. P., 1969a. Assimilation rate and growth of Lolium populations in the glasshouse in contrasting light intensities. Ann. Bot., 33, 951-955.

Wilson D., Cooper J. P., $\mathbf{1 9 6 9} b$. Effects of light intensity and carbon dioxide on apparent photosynthesis and its relationship with leaf anatomy in genotypes of $L$. perenne L.. New Phytol., 68, 628-644. 